\title{
Toward Explaining Communal and Ethnonational Resurgence and Separatism
}

\author{
Mumtaz Ahmad
}

Liberalism and the Quest for Islamic Identity in the Philippines, by Kenneth E. Bauzon. Published by the Acorn Press, Durham, NC, in association with Duke University Islamic and Arabian Development Studies, 1991, pp. xx + 219.

Ethnicity, Pluralism and the State in the Middle East, edited by Milton J. Esman and Itamar Rabinovich. Published by Cornell University Press, Ithaca and London, 1988, pp. viii +296 .

Ethno-National Movements of Pakistan, by Tahir Amin. Published by Institute of Policy Studies, Islamabad, Pakistan, 1988, pp. xxix +285.

Most of the scholarly writings on Muslim minorities have focused on the socioeconomic and political issues and religious concerns that tend to divide these minorities from the mainstream of their respective societies. Particular emphasis is often given to the religious nature of the conflict between the Muslim minority and the non-Muslim majority communities, especially as it relates to the processes of socioeconomic change and modernization in the larger society. This conflict is also explained in terms of integration versus separatism, universalism versus particularism, and secularism versus communalism. Theorists of the civil society persuasion have looked at the politics of minority unrest as essentially a product of socioeconomic changes brought about by the processes of modernization, including social mobilization, and the expansion of education and mass communication. Hence, according to this perspective, ethnic and religious particularism in postcolonial societies is a necessary concomitant of modernity. The statist view, on the other hand, regards the politics of religious and ethnic separatism as a function of public policies. Nothing is predetermined and inevitable; public policies can restructure and reshape the environment within which communal and ethnonational movements can either flourish or disappear.

Mumtaz Ahmad is an associate professor of political science at Hampton University, Hampton, Virginia. 
Bauzon's study of the struggle of Muslim separatism in the Philippines goes beyond both the civil society and the statist perspectives and locates the origins of the problem in the conflicting conceptions of nationality as articulated by Islamic and liberal paradigms. These opposing conceptions of self and community form a coherent ideology, resulting in a cosmology "that presupposed the unity of all things and events." Bauzon shows how the fate of the Philippine Muslims has been determined "by false images masquerading as "knowledge," much of which was produced by liberal social scientists with their delusions of objectivity and value-neutrality. The problem of the Moro Muslims, therefore, is not a problem caused by bullets and guns, but rather is one caused by the inherent and causally autonomous connection between two fundamentally opposed conceptual frameworks and their respective constructions of social reality. Both Islam and liberalism provide alternative strategies in constructing theories of what constitutes an appropriate basis for social organization. The crucial question is not whether these theories are right or wrong, but whether they have helped create an intellectual framework within which their adherents tend to construct their own visions of social reality.

Bauzon's fascinating and often provocative discussion on the positivist approach as a paradigmatic reference point for studying the issues of nation building and subnational formation raises interesting questions about relations between empirical social research and policy on the one hand, and between paradigms and social policy on the other. We know that paradigms influence the direction, content, and methods of social science research. But does social science influence social policy? Bauzon's answer is a categorical yes. However, as pointed out by Barber and others, knowledge has its effectiveness in conjunction with other factors, i.e., there is no simple and unmediated determinism of policy and sociopolitical consequences via the knowledge produced by social science research. A strong moral and political commitment of policy makers and a convenient convergence of "ideal" and "material" interests is a necessary prerequisite for knowledge to be translated into public policies.

As against the positivist view, which isolates theories and methodologies of social science from adulteration of values, Bauzon takes an interpretative view and believes in the social construction of reality, though maintaining a reciprocal relation between theory and praxis. In fact, Bauzon's view is more interactionist, as he emphasizes throughout his study the dynamic relationships between values, theories, interests, and policies. It is this interdependent relationship that forms the core of his argument throughout his book: how paradigms of the Islamic worldview and the liberal worldview form perceptions of self, community, ethnicity, and nation, and how these perceptions in turn determine the policies of the actors. Bauzon shows how the guardians of the central state in the Philippines, who oppose Muslim aspirations for religiocultural identity and political autonomy, tend to rationalize their opposition within a liberal 
paradigm that denies legitimacy to primordial bases of social organization and favors modern associational forms of organization. The liberal cultural framework invoked by the central political (read: Christian) elite, while dealing with the Philippine Muslims, becomes an oppressive instrument of state policy, albeit couched in such fashionable terms as state building, nation building, national integration, or Talcott Parson's famous pattern variables differentiating between modern and traditional societies. The Islamic framework within which the Muslim minority thinks and acts revolves around the concepts of tawhid (the oneness of God), God's revelation to humanity through the Prophet Muhammad, the establishment of a just social order based on Qur'anic injunctions, and a religiously based unity of the world Muslim community (ummah).

The significance of Bauzon's distinctive contribution lies in its perceptive and penetrating discussion of the relationship between narrative and social texts and in its brilliantly conceived arguments showing how social science paradigms, theories, and concepts influence social policy. Bauzon has given us a new perspective for looking at the problems of communal and ethnonational separatism in the contemporary world, a perspective grounded in sound theory, both normative and empirical.

Benjamin Barber, in his recent article in The Atlantic, has predicted that the world is faced with two political futures. The first is what he calls a "retribalization through large swaths of humankind by war and bloodshed," a "Lebanonization of national states in which culture is pitted against culture, people against people, tribe against tribe-a jihad in the name of a hundred narrowly conceived faiths against every kind of interdependence, every kind of artificial social cooperation and civic mutuality." The second future, a product of economic and ecological forces currently making their presences felt throughout the world, paradoxically brings nations into "one commercially homogeneous global network: one McWorld tied together by technology, ecology, communications, and commerce." The world is falling apart and coming together at the same time.

The first tendency is nowhere more visible and more assertive than in the resurgence of all those primordial forces which, according to the predictions of modernization theorists in the 1950s and $1960 \mathrm{~s}$, should have disappeared and vanished in the wake of the forces of modernization, economic development, and social change. One of the basic assumptions of modernization theory was that ascriptive and traditional loyalties such as those to caste, kinship, family, and even larger traditional bases of group formation-language, region, ethnicity, sect, religion - would become insignificant and less important as societies moved 
forward on the path of modernization and socioeconomic change. The processes through which these changes would come about included expansion in mass education, mass communication, urbanization, social and political mobilization, and state and nation building.

Yet it is now clear from the developments of the last two decades that although there has been considerable progress in mass education, mass communication, urbanization, and socioeconomic mobility, these processes have not resulted in social cohesion and national integration. On the contrary, modernization and socioeconomic change in most Third World societies have tended to strengthen the traditional bases of group formation and loyalties. Tribes, caste and kinship groups, and ethnonational and communal formations are rediscovering their primeval identities and are aggressively asserting their cultural agenda in the political arena. Ethnicity, sectarianism, and religion seem to have replaced ideologies both as major sources of group loyalties and political conflicts and violence in many societies. In South Asia, for example, people are fighting with one another not on the basis of the right and left of the political divide, but on the basis of distinctions between Hindus and Muslims, Hindus and Sikhs, Sinhalese and Tamils, Sunnis and Shi'ahs, and Sindhis and Muhajirs.

As a result of these developments, a revisionist modernization theory holds that political modernization tends initially not to weaken ethnonational sentiments but to strengthen them. The very process of state formation stimulates and stirs up sentiments of parochialism, communalism, and ethnonationalism because it introduces a new prize over which to fight and with which to fight: political power.

At the core of domestic political developments in most countries of the Middle East are the conflicts engendered by religioethnic diversity. The concept of a sovereign nation-state has yet to take its roots in a social context defined primarily by self-conscious and organized ethnic and religious communities with their own distinct identities. While the newly established nation-states have to operate on a relatively unsteady ground of legitimacy and have to cope with multiple challenges to their ability to expand their authority across vertical and horizontal lines, ethnoreligious particularities are firmly entrenched in the social structures of their societies and are capable of mustering enough resources to impair and destabilize the central states.

Ethnicity, Pluralism and the State in the Middle East is the first and most comprehensive attempt by a group of specialists on the Middle East to look at the ethnoreligious conflicts combining insights of area studies and social science research. Editors Esman and Rabinovich have put together fifteen essays which deal with the general questions of ethnicity, majority, minority, and ethnopolitics in the Middle Eastern states and attempt to draw on comparative data of the region as a whole.

Esman and Rabinovich set the stage for subsequent discussion with their 
excellent introductory essay on "The Study of Ethnic Politics in the Middle East." They begin by identifying four principal phases in the ethnic politics of the Middle East and in the literature on the subject during the past sixty years. Phase one, which ended with World War I, was characterized by the millah system that regulated the relationship between the Ottoman Empire and the diverse religious and ethnic groups that constituted the majority of its population. The millah system provided a considerable degree of internal autonomy to the large number of non-Muslim groups within the Ottoman Empire. Since the polity was based on religious solidarity, ethnicity did not play a very significant role in its political life. In fact, as Esman and Rabinovich point out, "most Arabs continued to view the Ottoman Sultans as their legitimate Muslim ruler" until the dismemberment of the empire. Phase two, which began with the dissolution of the Ottoman Empire, laid the foundations of a new state system in the Middle East, building on the concepts of territorial nationalism (Iran and Turkey) and Arab nationalism (Egypt, Syria, and Iraq). It is during this phase that we witness the emergence of ethnicity as a crucial factor in the process of defining boundaries between geographic entities, nation-states, and political communities. The population of most of these states, especially in the Fertile Crescent, was fragmented and divided into various sects and ethnic groups. Phase three, which began in the late 1940 s, saw a relative decline in the role of ethnicity in the wake of the decolonization process in the Middle East. Other factors that contributed to the relative marginalization of ethnicity during this phase included the superpowers' rivalry in the region, republican revolutions in Egypt and Iraq, massive socioeconomic changes in several Arab states, the rise of Arab nationalism and the quest for Arab unity, and, above all, the conflict with Israel. Phase four, which began in the 1970 s, is characterized by ethnic resurgence in almost all Middle Eastern states. Prominent cases of the militant resurgence of ethnonational movements during this phase include the collapse of confessional consociationalism in Lebanon, the Kurdish and Shi'ite revolts against the Iraqi state, the Sunni revolt against an Alawi dominated Syrian state, and Sephardi-Ashkenazi conflict in Israel. These developments, caused by both domestic policies of the states and regional forces, were also encouraged by the reinvigorated political role of Islam after the Islamic revolution in Iran and by the demise of competing ideologies such as Arab nationalism and socialism.

Esman and Rabinovich acknowledge that at present "there is no unified theory that empirical investigation can use as a guide." There are various competing perspectives and partial theories that social scientists have applied to explain the emergence and development of ethnonational movements. Most scholars agree, however, that at the core of ethnic conflicts lies the quest for "power, wealth, security, and status." Controversies between "primordialists" and "instrumentalists" raise interesting questions about the relative strength of ascriptive group loyalties on the one hand and the "adaptive and opportunistic 
quality of communal identities" on the other. Similarly, integration and conflict models of social analysis raise a different set of questions, as Bauzon points out in his study of the Philippines. While the integrationist model is interested primarily in value consensus, interdependency, and system maintenance, the conflict model directs our research efforts to discovering patterns of coercion, domination, and oppression. In the case of the Middle East, however, the pertinent question is whether the religious, subnational, sectarian, and racial solidarities "represent differences in kind, or only in the degree of pluralism."

The authors in this volume have not answered this question uniformly. Some, like Kedourie and Vatikiotis, believe that the origin of the ethnic problems in the Middle East lie in "Islamic exclusiveness" and is "peculiar to an ideological faith that is tied to temporal power that cannot be shared with others who are not of the same faith." Vatikiotis is especially emphatic on this point: an Islamic order, being a total system, "cannot entertain political pluralism, only political separatism." In fact, Vatikiotis paints a ghastly picture of the treatment of non-Muslim minorities in an Islamic society and maintains that only a secular political order that displaces Islam from the public sphere can ensure harmonious relations between various ethnic and religious communities in the Middle East. Kedourie, on the other hand, finds the problem so intractable that, according to him, even "the European vocabulary of politics and the modern European concepts of the state" cannot save the Middle East. Based on his analysis of the situation in Lebanon and Cyprus, the two countries where Western types of secular political arrangements were instituted to prevent ethnic mobilization, Kedourie argues that these arrangements did not lead to "greater welfare and security but to insecurity and destruction for the inhabitants of the two countries." The obvious conclusion one can draw from reading Vatikiotis and Kedourie is that nothing works in the Middle East, neither Islam nor secular democracy. Vatikiotis' "Islamic exclusiveness" thesis-blaming Islam for everything and relating all social and political ills to Islam-would be plausible only if he could show that religious minorities in non-Muslim societies (Jews in Eastern Europe; Muslims in India, Myanmar [formerly Burma], and the Philippines; and Tamils in Sri Lanka) were treated equally and fairly.

Esman, on the other hand, believes that problems associated with ethnic and religious pluralism in the Middle East can be understood and analyzed "within the same conceptual frameworks that have evolved from the recent experiences of other postcolonial states in Asia and Africa." Variations within the Middle East are as great as anywhere in other regions of the world. The challenge to the postcolonial state - "the universal macrostructure for political authority"-vis-à-vis coping with the politically mobilized ethnic and religious minorities and meeting the rising expectations of newly emerging social classes, often organized on ethnic or communal platforms, is common to the Middle East and to other regions of the world. The proliferation of ethnic minorities, the 
challenges of modernization and economic development, the limited resources and capabilities of the postcolonial state, and its susceptibility to external influences and interventions are not unique to the Middle East. Even the strategies to manage and regulate ethnic conflicts have no special Middle Eastern flavor. Regimes everywhere in the Third World are engaged in either rewarding acculturation and the eventual assimilation of ethnic minorities into the dominant community or in developing allegiance to nonethnic symbols and state institutions. Developing institutional structures for consociational politics and granting concessions of autonomy to ethnic and religious minorities are the other two common strategies adopted by regimes to manage ethnonational conflicts. What makes the Middle East distinctive, according to Esman, is its geopolitical situation, its Islamic and Ottoman heritage, and the presence of a large number of cultural, religious, and ethnic communities that transcend state boundaries.

Ethnicity, Pluralism, and the State in the Middle East is an important contribution to the study of ethnic and religious pluralism in the Middle East. It will be of enormous interest to the scholars of the Middle East and comparative politics. Esman's brilliant theoretical discussions on issues of ethnicity, modernization, and the postcolonial state will be of immense value to scholars of Third World politics.

$* \quad * \quad *$

Amin's study of Ethno-National Movements of Pakistan is an important contribution to the scholarship on ethnicity. Although conceived as a case study of Pakistan, Amin's work is based on sound theory and thorough policy analysis.

In recent years, ethnicity in Pakistan has emerged as a major source of political conflict and violence. There are many reasons to which this development could be attributed. First, the province of Punjab happens to be the largest province in the county; more than sixty percent of all Pakistanis live there. Second, due to historical and structural factors, and also because of the deliberate policies of the various regimes, all four Pakistani provinces did not experience an equal degree of socioeconomic development or receive an equitable share of national resources. Third, in the absence of democratic political institutions, the country was ruled during most of its independent existence by the military. It so happens that the majority of the armed forces' personnel came from Punjab, which gave rise to the perception of the smaller provinces that Punjab is dominating the rest of the country. Fourth, as violence in Bihar, Assam, and Gujarat over such issues as quotas, reservations, jobs, and school admission has shown, economic development, social mobility, political participation, and ethnic conflicts go hand in hand. The competitive political and economic struggle is launched on many fronts, including that of caste, ethnicity, and religion. One can witness this today in Sindh, where native Sindhis and Urdu-speaking 
Muhajirs are fighting with one another for a limited number of seats in professional schools and lucrative jobs in government and public corporations. In short, both structural factors and circumstantial contingents have combined to produce a situation that engenders ethnic violence and impairs the capacity of the central state to initiate and implement rational economic and administrative policies. Historically, state authorities in Pakistan have used Islam both as a source of legitimacy and as a source of national integration in a social context marred by ethnic, regional, and linguistic differences. However, as the separation of East Pakistan (now Bangladesh) has demonstrated, Islam is a necessary but not the only factor for national integration. It needs to be supplemented by other more concrete and mundane policy measures in order to ensure a more equitable distribution of national resources and to provide an institutional framework for broader political participation in national affairs. Unfortunately, Pakistani policy makers have so far failed to promote either socioeconomic justice or a participatory political process. As a result, economically depressed and politically disenfranchised ethnic and social groups have resorted to violence in order to press their demands and grievances.

But how serious is the threat of ethnic conflict for Pakistan's security and integrity as a nation-state? Most scholars of Pakistani politics have been drawing worst case scenarios and predicting the imminent demise of the Pakistani state. Ali's Can Pakistan Survive: The Death of a State (1983) and Harrison's In Afghanistan's Shadow (1981) boldly predicted that the Soviet Union's (!) aid to Pakistani ethnonational movements would eventually lead to the demise of the "Islamic banana republic." Ziring's Pakistan: The Enigma of Political Development (1980) makes the survival of Pakistan as an independent sovereign state its main theme and concludes that "Pakistan could cease to exist in its sovereign nation-state form." In fact, Ziring even suggested that with the approach of the twenty-first century, Pakistan could very well end up becoming a Soviet republic (!). Even Syed and Sayeed expressed serious doubts about the future of Pakistan as a nation-state.

These doomsday scenarios for Pakistan were all based on exaggerated views of the strength and potentially destabilizing power of the ethnonational movements in Sindh, Baluchistan, and the Northwest Frontier Province (NWFP). Amin subjects these scenarios to critical analysis and points out their flawed assumptions. According to Amin, two major assumptions underlie the literature on Pakistan's ethnic problems. The first one holds that ethnic identities are more basic and entrenched and that ethnonational movements based on these identities have an inevitable tendency to rise. Ahmad, Gankovsky, and Harrison are primarily guided by this assumption. They project the present situation of these groups to an immemorial past-mostly mythical-and try to show a continuous and unbroken stream of ethnonational consciousness throughout the centuries. They reconstruct an imagined history of these 
movements and show a continuous evolution of a single idea. Ali, Ziring, Sayeed, and Syed also tend to follow this line and assume a certain inevitability as regards the continuous rise of such movements.

Yet there is ample evidence to demonstrate the dynamic and changeable character of ethnicity. Recent studies have shown that ethnic groups hold multiple identities and that the hierarchical ranking of these identities keep changing. In a recent study of Zaire, Canada, and Belgium, Roosens (Creating Ethnici$t y, 1989)$ has shown that ethnic identity does not always stem from ancient tradition or a shared historical experience: "it can be shaped, modified, recreated, or even manufactured in contemporary society." Wallerstein has also shown in his studies of ethnicity in West Africa how the local colonial administration "created" new ethnic groups by mere census techniques - what Geertz called "ethnogenesis by census redefinition." In Northern Rhodesia (now Zambia), copper belt towns consisting of different tribes were grouped together as Nyasaland, and this manufactured grouping took on a real ethnic existence with the passage of time. Ahmad (Pakistan Society) also shows how "district ethnicity," a product of the British colonial administration in the NWFP, took on an identity of its own in the form of "Hazarwal." (The reverse problem, which Weiner calls "genocide by census redefinition," has also been documented. According to the 1941 census of India, there were 25 million tribal people; in the 1951 census, their number was given as only 1.7 million.)

In the case of Pakistan, for example, the Pushtun movement, which was quite active in the formative years of Pakistan, went into a complete decline in the 1980s, while the Jeeye Sind and Baluch movements, which had little support in the 1950s, gained substantial mass support in the 1980s. As against the "rise and rise" thesis of most scholars of Pakistani politics, Amin argues for a "rise and decline" thesis for ethnonational movements.

The second assumption of the doomsday scenario authors that Amin subjects to critical scrutiny is related to their belief that transborder connections among Pakistan's ethnic groups are disruptive to national integration within the country. That is, the impact of external events is inevitably negative and will contribute to the rise of Pakistani ethnonational movements. Amin argues that three analytically distinct factors have to be taken into consideration when dealing with the impact of external actors and events. First, international factors usually play a secondary role and assume primacy only in situations of domestic political crises. Second, the influence of the activities of coethnics living in adjacent states and the influence of these states' policies may neutralize each other. Third, the impact of international actors is not inevitably negative for national integration; it is rather an empirical question and is not to be determined in advance. External developments in the 1980s negatively influenced the Pushtun movement but positively encouraged the Baluch movement.

Amin believes that the majority of the students of Pakistani politics have 
erred because the dominant thrust of their theoretical base has been societycentered. They have generally focused on the rise of ethnonational movements from the perspective of the modernization processes, which has led them to believe in the continuous rise and growth of these movements.

Amin argues for an alternative approach, one which shifts the emphasis from a society-centered explanation to a state-centered explanation and which is in accord with the mainstream political science literature on the role of the states. We may note here that Amin's statist approach is not the same as that of Alavi's theory of the relative autonomy of the postcolonial state, which maintains that the state may formulate goals that are not simply reflective of the demands and interests of the dominant social groups in society. His policy thrust argues for a radical restructuring of state power, reflecting proportionate ethnic representation, and implementing the consequent policy measures based on an equitable distribution of national resources and respect for cultural pluralism. Amin believes that if the political policies of the state elite led to greater power sharing among ethnic groups, local ethnonational movements would decline. In line with Bauzon and Esman, Amin also argues that in the absence of power sharing, the economic and cultural politics put forward by the state's elite to reduce ethnic conflict may in fact turn out to be counterproductive.

Skocpal has argued (States and Social Revolutions, 1978) that revolutions take place not when the classes are strong, but when the state is weak. In concluding this review essay, let us reconsider the questions we raised earlier: how serious is the threat of ethnic conflict for the Pakistani state? If Skocpal is right, we should not worry too much about the developments in civil society, but rather focus our attention on the capacity of the state. In the case of Pakistan, one can argue that the ruling institutions - the higher bureaucracy and the military, the two pillars and guardians of the Pakistani state-are the least affected by ethnic conflict. The steel frame which the British colonial administration built is still very much entrenched. The corporate and institutional interests of the higher bureaucracy and the military predominate via their ethnic and sectarian affiliations. Thus, as long as the guardians of the state remain institutionally cohesive, united, and homogeneous, ethnic and sectarian conflict will remain manageable, although their nuisance value should not be minimized. The state's coercive apparatus is more than enough to take on any ethnonational challenge to its territorial integrity. But this is only a partial answer to our question, for it only maintains that Pakistan can successfully meet the ethnonational challenge to its integrity. What it does not say is that the state will escape perpetual and bitter embroilment in an incessant conflict with discontented ethnic groups if it does not incorporate these groups' concerns, demands, and interests in its policy agenda. 


\section{References}

Ahmad, Akbar S. Pakistan Society. Karachi: Oxford University Press, 1984. Ahmad, Mumtaz. "Class, Religion and Power: Some Aspects of Islamic Revivalism in Pakistan.” Ph.D. Thesis, University of Chicago, 1990. Alavi, Homza and T. Shanon, eds. Sociology of Developing Societies. New York: Harcourt and Brace, 1982.

Ali, Tariq. Can Pakistan Survive: The Death of a State. London: Zed Books, 1983.

Barber, Benjamin R. "Jihad vs. McWorld." The Atlantic 269, no. 3 (March 1992): 53-63.

Gankovsky, Yuri V. The People of Pakistan: An Ethnic History. Moscow: Nauka Publishing House, 1971.

Geertz, Clifford (ed.). Old Societies and New States. New York: The Free Press, 1963.

1973.

Harrison, Selig S. In Afghanistan's Shadow: Baluch Nationalism and Soviet

Temptations. New York: Carnegie Endowment for International Peace, 1981.

Hayes, Louis. Politics in Pakistan. Boulder, CO: Westview Press, 1984. Roosens, Eugeen. Creating Ethnicity. Beverly Hills, CA: Sage Publications, 1989.

Sayeed, K. B. Politics in Pakistan: The Nature and Direction of Change.

New York: Praeger, 1980.

Skocpal, Theda. States and Social Revolutions: A Comparative Analysis of

France, Russia, and China. Cambridge, UK: Cambridge University

Press, 1979.

Syed, Anwar. Islam and National Integration in Pakistan. New York:

Praeger, 1984.

Wallerstein, Immanual. "The Emergence of Two West African Nations:

Ghana and the Ivory Coast.” Ph.D. Thesis, Columbia University, 1959. ed. Social Change: The Colonial Situation. New York: Wiley,

1966.

Africa: The Politics of Unity. New York: Random House, 1967.

Ziring, Lawrence, Pakistan: The Enigma of Political Development. London, Wm. Dawson, 1980. 